\title{
Hepatitis B virus DNA in Blood Donors Positive of Anti-Hepatitis B Core Antibodies and Negative for Surface Antigen in Hawler Major Blood Bank, Kurdistan Region, Iraq
}

\author{
Rasha N. Hassan* \\ Ali H. Hussain**
}

\author{
MBChB \\ MBChB, MSc, PhD (Microbiology)
}

\section{Abstract:}

Background: Occult Hepatitis B virus infection (OBI) among blood donors is an important medical concern.

Objectives: This study was done to detect the presence of occult hepatitis B virus infections among blood donors with negative hepatitis B surface antigen and positive total anti-hepatitis B core antibodies in Hawler Major Blood Bank in Hawler city/Kurdistan Region of Iraq.

Fac Med Baghdad 2018; Vol.60, No.1 Received: Dec., 2017 Accepted: Mar., 2018

Methods: A total number of 12,185 blood donors in Hawler Major Blood Bank were screened for $\mathrm{HBsAg}$ and total anti-HBcAb using ELISA technique, and then positive results were retested by confirmatory technique by Chemiluminescence assay. All $\mathrm{HBsAg}-\mathrm{HBcAb}+$ were selected as the study group; HBV DNA was tested among $\mathrm{HBsAg}-/ \mathrm{HBcAb}+$ by conventional PCR and Real time-PCR. Clinical and demographic data of study group were recorded.

Results: Among the 12,185 blood donors, HBsAg was positive in $27(0.22 \%)$ donors using Chemiluminescence assay, the frequency of $\mathrm{HBs} \mathrm{Ag}-/ \mathrm{HBc} \mathrm{Ab}+$ was 276 (2.27\%), and then the total prevalence of $\mathrm{HBV}$ infection in all blood donors was $2.49 \%$. Among the $276 \mathrm{HBs} \mathrm{Ag}-/ \mathrm{HBcAb}+$, occult hepatitis B virus infection (OBI) was positive in 39.1\% (108/276) using conventional PCR and Real time-PCR techniques, while the prevalence among all blood donors $(n=12,185)$ was $0.09 \%$. Testing of HBV-DNA in HBs $\mathrm{Ag}-/ \mathrm{HBc} \mathrm{Ab}+$ group for $\mathrm{OBI}$ was done by qualitative PCR (positive HBVDNA=102/276) or by quantitative Real time-PCR (positive HBV-DNA=108/276).

Conclusions: The OBI is frequently detected among blood donors in Hawler city especially those have $\mathrm{HBsAg} / \mathrm{HBcAb}+$, and the total anti-HBcAb is an essential serological marker for screening $\mathrm{HBV}$ among blood donors. The risk factors for developing OBI among blood donors should be elucidated.

Keywords: Blood donors, Occult HBV, Hawler city, Blood Bank.

\section{Introduction:}

The safety of blood in blood bank is an important global issue, as blood transfusion is a vital therapeutic procedure (1); the prevention of pathogen transmission through blood transfusion is a challenging subject. The presence of new cases of hepatitis B virus infections is continue to occur despite screening testing of $\mathrm{HBV}$ using $\mathrm{HBs} \mathrm{Ag}$ with highly sensitive and specific techniques (2). Many blood banks have added antibodies specific to Hepatitis B core antigen (anti-HBc Abs) as a second HBV marker for detection HBV infections (3). The presence of anti-HBc Abs in absence of $\mathrm{HBs} \mathrm{Ag}$ positivity has two scenarios: either blood donor was infected and now cured from infection or the donor is still infected and the infection can be elucidated by viral nucleic acid amplification technique (4). The Blood donor with serological evidence of negative $\mathrm{HBs} \mathrm{Ag}$, positive or negative $\mathrm{HBc} \mathrm{Abs}$, and positive HBV nucleic acid is known as occult HBV infection $(5,6)$. This infection is a hidden source of HBV transmission, not only through blood in blood bank, but also to families of infected patients. This study was conducted to detect the prevalence of

*Microbiology/Pathology, Kurdistan Board of Medical Specialties/ Kurdistan region.

** Dept. of Community Health, Technical College of Health, University of Sulaimani Polytechnic.

Email: Ali.hussain@spu.edu.iq, occult hepatitis $\mathrm{B}$ virus infections among blood donors negative for $\mathrm{HBsAg}$ and positive for total anti-HBc antibodies in Hawler Major Blood Bank.

\section{Methodology:}

During a period of three months (from January till March 2017), volunteer blood donors in Hawler Major Blood Bank were routinely tested for $\mathrm{HBs} \mathrm{Ag}$ by ELISA technique (HBsAg/Biorad/France) and total anti-HBc Abs using ELISA technique (Total Anti-HBc Abs/Biorad/ France); donors with negative $\mathrm{HBs} \mathrm{Ag}$ and positive total anti-HBc Abs were our target study population and blood samples were aspirated from two hundred and seventy six $(n=276)$ donors with $\mathrm{HBsAg}-/ \mathrm{HBcAb}+$. Written informed consent was obtained from blood donors with $\mathrm{HBsAg}-\mathrm{HBcAb}+$ who accepted participation in the study. The aspirated blood from each donor in the study group was centrifuged and each serum sample was divided into four aliquots of $1.5 \mathrm{ml}$ tubes then stored in deep freeze $\left(-70^{\circ} \mathrm{C}\right)$ until examined. Rechecking of HBsAg and total anti$\mathrm{HBcAb}$ for the all 276 samples using Chemiluminescence kits (LIAISON® HBs, LIAISON® Anti-HBc kits/Diasorin/Italy) was done, and then polymerase chain reaction (PCR) technique was performed on all 276 sera of the study group to detect HBV. Both qualitative and quantitative Real time-PCR techniques were done. Qualitative PCR was done by extraction of viral DNA with Sinaclon 
DNP extraction kit (Sinaclon Company/Iran then amplification with Hepatitis B Virus PCR Detection Kit (Sinaclon Company/Iran), while quantitative PCR was achieved by extraction with Exprep Plus viral DNA/RNA kit (Bioneer Company/ Republic of Korea) and amplification with Accupower HBV Quantitative PCR kit (Bioneer Company/ Republic of Korea). The purity of DNA yield by extraction was quantified by NanoDrop 2000 spectrophotometer (ThermoFisher Scientific Company/USA). Demographic and clinical data were gathered from each participant in the study. The results were analyzed using SPSS program.

\section{Results:}

A total number of 12,185 blood donations were screened for hepatitis B virus infection using two serological markers: $\mathrm{HBsAg}$ and total anti-HBcAb. The combination of positive $\mathrm{HBsAg}$ and anti-HBc Abs were found in 27 donors, while 276 donors were $\mathrm{HBsAg}$-/anti-HBcAb+. The prevalence of HBV infection among blood donors during the period of sample collection was $2.49 \%$, and the prevalence of $\mathrm{HBs} \mathrm{Ag}-/ \mathrm{HBc} \mathrm{Ab}+$ was $2.27 \%$, while the prevalence of positive $\mathrm{HBsAg}$ was $0.22 \%$. Two molecular techniques, quantitative and qualitative PCR techniques, were used for detecting HBV nucleic acid in $\mathrm{HBs} \mathrm{Ag}-\mathrm{HBc}$ Abs+ blood donors and the results showed that $39.1 \%(108 / 276)$ of them were positive for $\mathrm{HBV}$ in real time-PCR, while $37 \%$ were positive in qualitative (conventional) PCR, the differences were statistically not significant (table 1). Depending on RT-PCR results of HBV load, the prevalence of OBI among blood donors in Hawler Major Blood Bank was $0.09 \%$, and the prevalence of OBI among $\mathrm{HBs} \mathrm{Ag}-/ \mathrm{HBc} \mathrm{Ab}+$ was $39.1 \%$.

Table (1): HBV nucleic acid positivity in HBsAg negative/HBc Abs positive blood donors

\begin{tabular}{llll}
\hline $\begin{array}{l}\text { Molecular } \\
\text { Technique }\end{array}$ & $\begin{array}{l}\text { Positive } \\
(\%)\end{array}$ & $\begin{array}{l}\text { Negative } \\
(\%)\end{array}$ & \begin{tabular}{l} 
Total $(\%)$ \\
\hline Real time PCR
\end{tabular} \\
$\begin{array}{llll}(308 & 168 & 276 \\
(60.9 \%) & (100 \%)\end{array}$ \\
\hline Qualitative PCR & $102(37 \%)$ & $174(63 \%)$ & $\begin{array}{l}276 \\
(100 \%)\end{array}$ \\
\hline
\end{tabular}

For the 108 positive HBV load by Real time-PCR, the mean of the HBV PCR viral load is 11996 copies $/ \mathrm{ml}$, the median is $89.5 \mathrm{copies} / \mathrm{ml}$, and the range is $19-308000$ copies $/ \mathrm{ml}$. The mean age of OBI was $42.72 \pm 10.988$; most of blood donors in study group were males $273(98.91 \%)$, while only 3 (1.09\%) were females, and all OBI were males. Most of $\mathrm{HBsAg} / \mathrm{HBcAb}+$ blood donors were having blood group $\mathrm{O}+$, while the other blood groups in descending sequence were $\mathrm{B}+, \mathrm{A}+, \mathrm{O}-, \mathrm{A}-$, $\mathrm{AB}+$, and $\mathrm{AB}-$ (table 2). None of the OBI donors was $\mathrm{B}-$, or $\mathrm{AB}-$, and most of them were $\mathrm{O}+$ and the overall differences in blood groups between OBI donors and other donors with negative HBV nucleic acid was statistically not significant $\mathrm{p}>0.05$, figure (1).
Table (2): Blood groups of blood donors with HBs Ag negative /HBc Ab positive

\begin{tabular}{lll}
\hline Blood group & Frequency & Percent \\
\hline $\mathrm{O}+$ & 117 & 42.4 \\
\hline $\mathrm{B}+$ & 66 & 23.9 \\
\hline $\mathrm{A}+$ & 48 & 17.4 \\
\hline $\mathrm{O}-$ & 24 & 8.7 \\
\hline $\mathrm{A}-$ & 6 & 2.2 \\
\hline $\mathrm{AB}+$ & 12 & 4.3 \\
\hline $\mathrm{AB}-$ & 3 & 1.1 \\
\hline Total & 276 & 100.0 \\
\hline
\end{tabular}

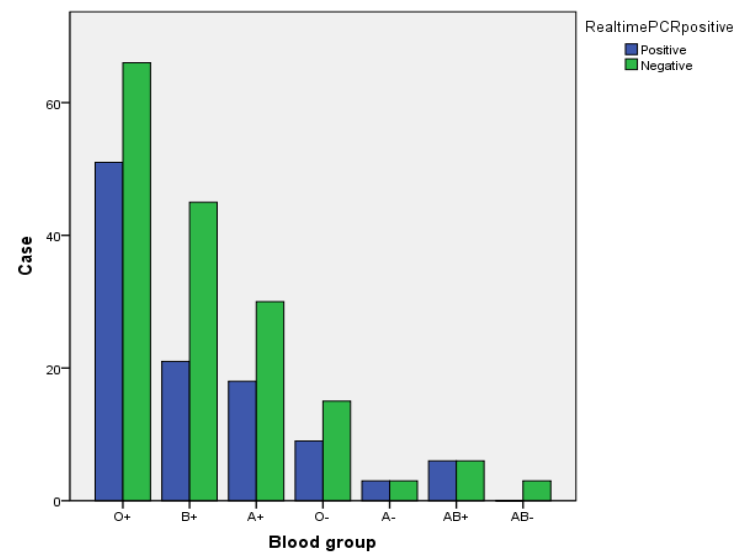

Figure (1): frequency of blood groups among positive HBV nucleic acid (OBI) and negative HBV nucleic acid groups.

Concerning the occupation of blood donors of both groups, OBI group $(n=108)$ and negative HBV DNA group $(n=168)$, most of them were working in free business and employees, while few of them retired or unemployed, and no significant statistical differences were present in professions of all $\mathrm{HBsAg}-/ \mathrm{HBcAb}+$, figure (2).

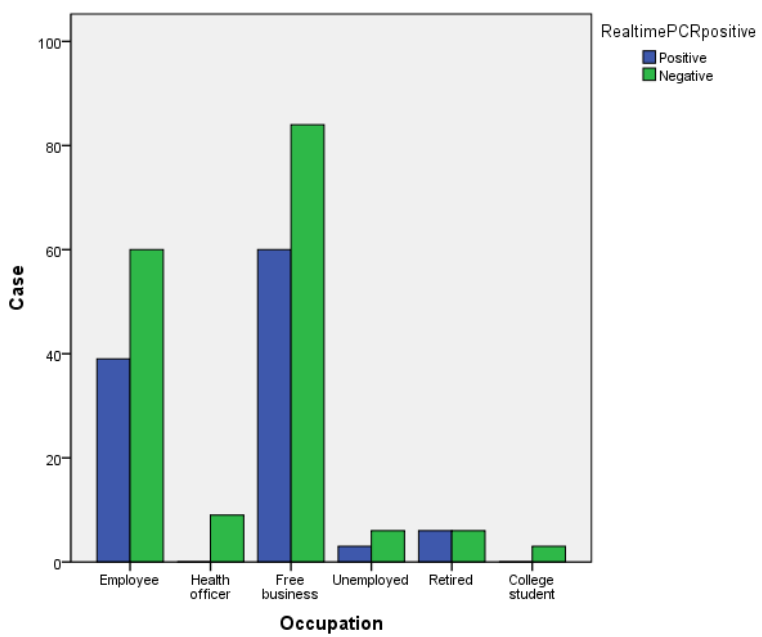

Figure (2); the professions of HBs Ag negative / HBc Abs positive blood donors.

The residency of blood donors with $\mathrm{HBs} \mathrm{Ag}-/ \mathrm{HBc}$ $\mathrm{Ab}$ revealed that most of them are living in city center districts while few of the Real time-PCR 
negative group was living in villages but none of RT-PCR positive group was living in a village, figure (3).

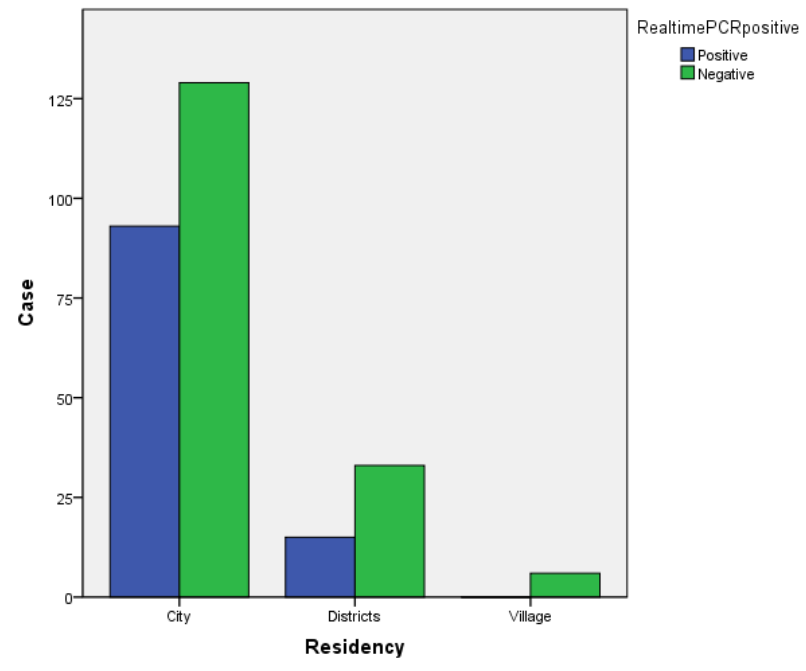

Figure (3): The residency of blood donors with negative HBs Ag/positive HBcAb.

The significance of differences in clinical data between OBI group $(n=108)$ and negative HBV DNA $(n=168)$ showed that donation and receiving of blood, history of contact with HBV infected persons, history of surgical operations, and history of jaundice were not statistically significant while history of chronic diseases and History of tattooing or skin piercing were statistically significant, table (3). The history of HBV vaccination was positive in only 5 donors of OBI group and in only 16 donors of HBV DNA negative group, while all the remaining were not vaccinated against HBV. The difference in history of HBV vaccination was statistically not significant $(p=0.0816)$, figure $(4)$. The correlation between total DNA yield concentration for each sample extracted by viral DNA/RNA kit, and measured by NanoDrop spectrophotometer, with the viral load of HBV measured by RT-PCR showed no linear correlation between the two results $(r=$ 0.042).

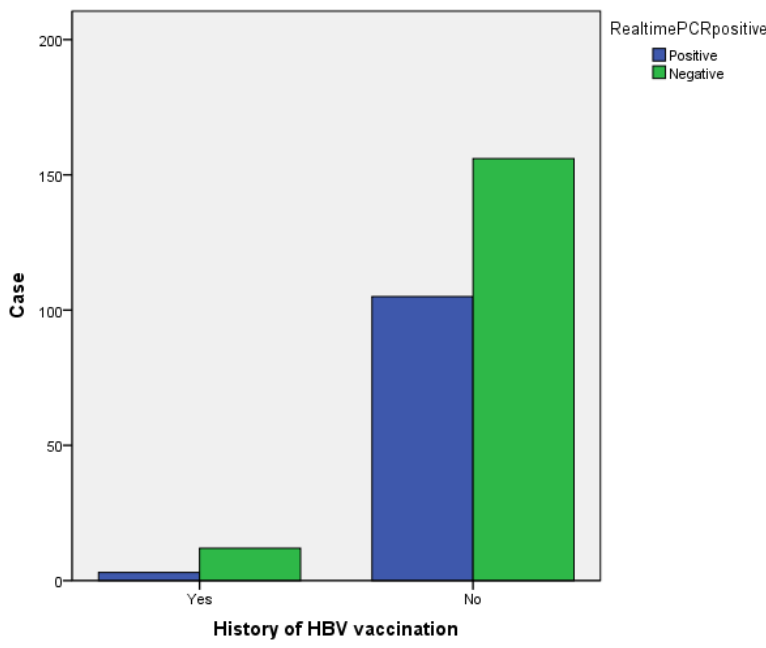

Figure (4): History of vaccination among OBI and those with negative HBV load.
Table (3): Clinical data of positive $\mathrm{HBV}$ nucleic acid (OBI) compared to negative OBI blood donors, both having negative HBs Ag/positive anti-HBcAb.

\begin{tabular}{|c|c|c|c|c|}
\hline \multirow{3}{*}{ Parameter } & \multirow{3}{*}{ Outcome } & $\begin{array}{l}\text { Real } \\
\text { positivity }\end{array}$ & time-PCR & \multirow{3}{*}{$\begin{array}{l}\text { P value } \\
\text { (Signifi- } \\
\text { cance } \\
\text { at } p< \\
0.05 \text { ) }\end{array}$} \\
\hline & & $\begin{array}{l}\text { Positive } \\
\text { (OBI) }\end{array}$ & Negative & \\
\hline & & Count & Count & \\
\hline \multirow{2}{*}{$\begin{array}{l}\text { History of } \\
\text { blood donation }\end{array}$} & Yes & 108 & 168 & \multirow{2}{*}{0.7537} \\
\hline & No & 0 & 0 & \\
\hline \multirow{2}{*}{$\begin{array}{l}\text { History of } \\
\text { receiving blood }\end{array}$} & Yes & 3 & 9 & \multirow{2}{*}{0.3051} \\
\hline & No & 105 & 159 & \\
\hline \multirow{2}{*}{$\begin{array}{l}\text { History of } \\
\text { contact } \begin{array}{r}\text { with } \\
\text { HBV infected }\end{array} \\
\text { persons }\end{array}$} & Yes & 18 & 42 & \multirow[b]{2}{*}{0.1014} \\
\hline & No & 90 & 126 & \\
\hline \multirow{2}{*}{$\begin{array}{l}\text { History of } \\
\text { chronic disease }\end{array}$} & Yes & 21 & 18 & \multirow{2}{*}{0.0421} \\
\hline & No & 87 & 150 & \\
\hline \multirow{2}{*}{$\begin{array}{l}\text { History } \\
\text { surgical } \\
\text { operation }\end{array}$} & Yes & 18 & 33 & \multirow{2}{*}{0.5341} \\
\hline & No & 90 & 135 & \\
\hline \multirow{2}{*}{$\begin{array}{l}\text { History } \\
\text { Jaundice }\end{array}$} & Yes & 3 & 0 & \multirow{2}{*}{0.0593} \\
\hline & No & 105 & 168 & \\
\hline \multirow{2}{*}{$\begin{array}{ll}\text { History } & \text { of } \\
\text { tattooing } & \text { or } \\
\text { skin piercing } & \end{array}$} & Yes & 0 & 9 & \multirow[b]{2}{*}{0.0368} \\
\hline & No & 108 & 159 & \\
\hline
\end{tabular}

\section{Discussion:}

The occult HBV infected blood donors can transmit infection to others. The absence of HBs Ag and the persistence of HBV nucleic acid in the blood or in hepatocytes is the hallmark of occult HBV. The prevalence of positive HBs Ag among blood donors in this study is much lower than the corresponding HBV marker in most regions of Iraq, for example in Duhok it is $0.78 \%$ (7), in Baghdad it is $0.6 \%$ (8), in Babylon governorate $0.7 \%$ (9), in Najaf governorate $0.66 \%$, and $3.5 \%$ in Karbala (10), the prevalence of $\mathrm{HBs}$ Ag was higher than the that recorded in Basra, $0.02 \%$ (11). The HBs Ag was also screened in neighboring countries, in Kuwait, in 2002, it was $1.1 \%$ among Kuwaiti blood donors (12); in Jordan, it was $1.4 \%$ (13), while in Denizli, Turkey it was $0.97 \%$ (14). The prevalence of HBV infection in the current study was $2.49 \%$, which is close to that recorded among blood donors ( $2.3 \%)$ in Basra in2013 (11), but less than a study in Erode District, India which recorded a prevalence of $10.9 \%$ (15). The present study measured the prevalence of HBs $\mathrm{Ag} \mathrm{-/} \mathrm{HBc} \mathrm{Ab}+$ among blood donors in Hawler Major Blood Bank and it was $2.27 \%$. A Previous national survey in Iraq tested $\mathrm{HBs} \mathrm{Ag}-/ \mathrm{HBc} \mathrm{Ab}+$ in all over Iraqi governorate and it was $8.1 \%$ (16), while two studies in Basra recorded 2.1\%, 18.58\%, $(11,17)$. OBI was detected in $0.09 \%$ of all blood donors during the study period and it was $39.1 \%$ among $\mathrm{HBs} \mathrm{Ag}-/ \mathrm{HBc} \mathrm{Ab}+$. Absence of $\mathrm{HBsAg}$ may be due to mutated HBsAg, low level expression of $\mathrm{HBsAg}$ or entrapment of antigen in the circulatory immune complexes (18). The prevalence of OBI in Iraq recorded in $3.9 \%$ of blood donors in Diyala (19), while in Basra it was $14 \%$ in HBc Abs positive donors (17). In nearby and abroad countries, the frequency of OBI was reported $0 \%$ in Turkey, Iran, and Greece (20-22), $1.25 \%$ in Saudi Arabia 
(23), $1.59 \%$ in Germany (24), $4.86 \%$ in Italy (25), $7.5 \%$ in India (26), $17.2 \%$ in Egypt (27), $38 \%$ in Japan (28) and $90.5 \%$ in Sudan (29). In the current study the mean and median of HBV DNA load among OBI were low, 11996 copies/ml and 89.5 copies/ml respectively, these results are in accordance to results of Ye X, et al (30) and to the general impression that $\mathrm{OBI}$ is characterized by very low HBV DNA load (31). In this study, most of OBI are in their $5^{\text {th }}$ decade of age and are male gender, and most of clinical and demographic data, with the exception of history of chronic diseases, are not significant risk factors for the development of $\mathrm{OBI}$ and $\mathrm{HBs} \mathrm{Ag}-/ \mathrm{HBcAb}+$. While a study by Said $\mathrm{ZN}$ et al demonstrated that age of OBI is mostly below thirty (32). The Concentration of DNA yield from viral DNA extraction has no correlation with the HBV load, this is an interesting finding which might be due to other nonspecific viral nucleic acids extracted which are not amplified by HBV amplification PCR kit.

\section{Conclusions:}

HBV infection among blood donors in Hawler Major Blood Bank is $2.49 \%$, and the prevalence of $\mathrm{HBs} \mathrm{Ag}-/ \mathrm{HBc} \mathrm{Ab}+$ is $2.27 \%$. The OBI is frequently detected among blood donors in Hawler city especially those have $\mathrm{HBsAg}-/ \mathrm{HBcAb}+$, and the total anti-HBcAb is an essential serological marker for screening HBV among blood donors. The introduction of Real time-PCR in screening of HBV in blood banks in Iraq is a vital screening tool. The risk factors for developing OBI among blood donors should be elucidated.

\section{Authors' contributions:}

Ali Hattem Bayati: designed the aim of the study and methodology.

Rasha Nazar Hassan: performed the laboratory tests and data collection. Both researchers analyzed data and wrote the manuscript.

\section{References:}

1. Osaro E, Charles AT. The challenges of meeting the blood transfusion requirements in Sub-Saharan Africa: the need for the development of alternatives to allogenic blood. Journal of blood medicine. 2011; 2:7-21. doi:10.2147/JBM.S17194.

2. Candotti D, Allain JP. Transfusion-transmitted hepatitis B virus infection. J Hepatol. 2009; 51:798809.

3. Sawke NG, Sawke G. Preventing PostTransfusion Hepatitis by screening blood donors for IgM Antibody to Hepatitis B core antigen. Journal of Global Infectious Diseases. 2010; 2(3):246-247.

4. Molijn MH, van der Linden JM, Ko LK, Gorgels $J$, Hop W, van Rhenen DJ. Risk factors and anti$\mathrm{HBC}$ reactivity among first time blood donors. Vox Sang. 1997; 72:207-10.

5. Seo DH, Whang DH, Song EY, Han KS. Occult hepatitis $B$ virus infection and blood transfusion. World Journal of Hepatology. 2015; 7(3):600-606.
6. Raimondo G, Pollicino T, Cacciola I, Squadrito G. Occult hepatitis B virus infection. J Hepatol. 2007; 46: 160-170.

7. Rasheed Hussein N, Mohamad Haj S, Amin Almizori L, Ahmed Taha A. The Prevalence of Hepatitis $B$ and $C$ Viruses Among Blood Donors Attending Blood Bank in Duhok, Kurdistan Region, Iraq, Int J Infect. 2017 ;4(1):e39008.

8. Ataallah TM, Hanan KA, Maysoun KS, et al. Prevalence of hepatitis $B$ and $C$ among blood donors attending the National Blood Transfusion Center in Baghdad, Iraq from 2006-2009. Saudi Med J 2011;32:1046-50.

9. Al-Juboury AWF, Salih HA, Al-Assadi MK, et al. Seroprevalance of hepatitis $B$ and $C$ among blood donors in Babylon Governorate- Iraq. Med J Babylon 2010;7:1-2.

10. Mahmood AK, Addose SA, Salih HA, et al. Seroprevalence of $\mathrm{HBs}$ ag and Anti $\mathrm{HCV}$ positive blood donors in Najaf governorate. Iraqi $J$ Community Med 2001;14:29-33.

11. Al-Rubaye A, Tariq Z, Alrubaiy L. Prevalence of hepatitis $B$ seromarkers and hepatitis $C$ antibodies in blood donors in Basra, Iraq. BMJ Open Gastroenterology. 2016;3(1):e000067.

12. Ameen $R$, Sanad N, Al-Shemmari $S$, et al. Prevalence of viral markers among first-time Arab blood donors in Kuwait. Transfusion 2005;45:197380.

13. Al-Gani EA. Prevalence of HBV, HCV and HIV1, 2 infections among blood donors in Prince Rashed Ben Al-Hassan Hospital in North Region of Jordan. Int J Biol Med Res 2011;2:912-16.

14.kalın, S, Baskan, B, Sacar, S, et al. Seroprevalence of HBsAg, Anti-HCV and RPR in blood donors in Denizli, Turkey. Klimik Dergisi/Klimik Journal. 2011; 24. 101-104.

15. Lavanya T, Viswanathan S, Arul Sheeba Malar $A$, et al. Prevalence of hepatitis $B$ virus infection among blood donors with antibodies to hepatitis $B$ core antigen. International Journal of Medicine and Medical Sciences. 2012; 4(6): 128-137.

16. Al-Naaimi, Ahmed. (2013). Epidemiology of Viral Hepatitis $B$ and $C$ in Iraq: Analysis of $a$ national survey 2005-2006. ZANCO Journal of Medical Sciences. 17. 370-380.

17. Abdulrazzak, Shawky \& Al-Aboudi, Kassid \& AlHmudi, Hayder. Some of immunogenetic status of HBsAg negative, HBcAb positive Blood donors in Basra province-Iraq. Scholars Research Library/Annals of Biological Research. 2015. 47-54. 18. Karimi G, Zadsar M, Vafaei N, Sharifi Z, FalahTafti M. Prevalence of antibody to Hepatitis $B$ core antigen and Hepatitis B virus DNA in HBsAg negative healthy blood donors. Virology Journal. 2016;13:36.

19. Abdulrazak SH. Hasan. Prevalence of Antibodies to Hepatitis B Virus Antigens and Occult Hepatitis B Virus Infection in Blood Donors. Diyala Journal of Medicine. 2012; 3(1): 57-61.

20. Findik D, Arslan U, Baykan M. Determination of hepatitis $B$ virus DNA incidence, viral load, and 
mutations in blood donors with HBsAg and anti$H B$-negative serology and antibodies to hepatitis $B$ core antigen. Eur J Intern Med. 2007;18:571-5. doi: 10.1016/j.ejim.2007.07.001. [PubMed] [Cross Ref]

21. Karimi G, Zadsar M, Vafaei N, Sharifi Z, FalahTafti M. Prevalence of antibody to Hepatitis $B$ core antigen and Hepatitis B virus DNA in HBsAg negative healthy blood donors. Virology Journal. 2016;13:36.

22. Zervou EK, Dalekos GN, Boumba DS, Tsianos $E V$. Value of anti-HBc screening of blood donors for prevention of $\mathrm{HBV}$ infection: results of a 3-year prospective study in Northwestern Greece. Transfusion. 2001;41:652-8. doi: 10.1046/j.15372995.2001.41050652.x.

23. Zekri AR, Awlia AA, El Mahalawi H, Ismail EF, Mabrouk GM. Evaluation of blood units with isolated anti $H B C$ for the presence of $H B V D N A$. Dis Markers. 2002;18:107-10.

24. Schmidt M, Nubling CM, Scheiblauer H, Chudy $M$, Walch LA, Seifried E, et al. Anti-HBc screening of blood donors: a comparison of nine anti-HBC tests.

25. Manzini P, Girotto M, Borsotti R, Giachino $O$, Guaschino $R$, Lanteri $M$, et al. Italian blood donors with anti-HBc and occult hepatitis B virus infection. Haematologica. 2007;92:1664-70.

26. Asim M, Ali R, Khan LA, Husain SA, Singla R, Kar P. Significance of anti-HBc screening of blood donors and its association with occult hepatitis $B$ virus infection: Implications for blood transfusion. Indian J Med Res. 2010;132:312-7.

27. Asim M, Ali R, Khan LA, Husain SA, Singla R, Kar P. Significance of anti-HBc screening of blood donors and its association with occult hepatitis $B$ virus infection: Implications for blood transfusion. Indian J Med Res. 2010;132:312-7.

28. Yotsuyanagi H, Yasuda K, Moriya K, Shintani Y, Fujie $H$, Tsutsumi $T$, et al. Frequent presence of $H B V$ in the sera of HBsAg-negative, anti-HBcpositive blood donors. Transfusion. 2001;41:10939.

29. Mahmoud OA, Ghazal AA, Del Metwally S, Elnour AM, Yousif GE. Detection of occult hepatitis $B$ virus infection among blood donors in Sudan. J Egypt Public Health Assoc. 2013;88:14-8.

30. Ye X, Li T, Xu X, et al. Characterization and follow-up study of occult hepatitis $B$ virus infection in anti-HBc-positive qualified blood donors in southern China. Blood Transfusion. 2017;15(1):612.

31. Said ZNA. An overview of occult hepatitis B virus infection. World Journal of Gastroenterology : WJG. 2011;17(15):1927-1938.

32. Said ZN, El Sayed MH, Salama II, et al. Occult hepatitis $B$ virus infection among Egyptian blood donors. World Journal of Hepatology. 2013;5(2):6473. 